Klaudia Miśkowicz

\title{
WOLNA OJCZYZNA - DAR I ZOBOWIĄZANIE
}

Setna rocznica odzyskania niepodległości przez Polskę skłania do głębszej refleksji nad znaczeniem pojęć „ojczyzna”, „naród”, „wolność”. Jest to problem ważny również dlatego, że obecnie daje się zaobserwować działania mające na celu podważenie wartości tradycji, narodu i patriotyzmu; Jan Galarowicz pisze o „zmowie milczenia”, a także o wypieraniu powyższych wartości przez ideologie postmodernizmu i kulturowego liberalizmu ${ }^{1}$. Twierdzi on, że dumę narodową utożsamia się obecnie z szowinizmem i ksenofobią. Taka niepokojąca diagnoza współczesnego społeczeństwa wzywa do przemyślenia i zdefiniowania na nowo terminów ojczyzna, naród i patriotyzm. W niniejszej pracy spróbuję przyjrzeć się tym pojęciom w kontekście myśli Jana Pawła II.

\section{Wolność osoby woła o wolność narodu}

Chrześcijańska antropologia uważa wolność za jedną z podstawowych cech osoby. Bóg stworzył człowieka wolnym, bo tego wymaga miłość rozumiana jako wybór osoby. Bóg nie stworzył niewolników oddających mu cześć z przymusu, ale ludzi wolnych, którzy mogą odmówić składania mu hołdu. Można powiedzieć, że wolność przynależąca do natury osoby stanowi aksjomat chrześcijańskiej wizji człowieka.

W swojej książce pt. Osoba i czyn Karol Wojtyła ukazuje dwa aspekty ludzkiej wolności; samo-posiadanie oraz samo-panowanie. Oba te aspekty są integralną częścią samostanowienia osoby, ponieważ człowiek może stanowić tylko o tym, co posiada oraz stanowić może tylko o tym, nad czym panuje. Wojtyła używa terminu „panować sobie”: zwierzę sobie nie panuje, lecz panuje sobie człowiek

\footnotetext{
${ }^{1}$ Por. J. Galarowicz, Wprowadzenie do antropologii filozoficznej, Kęty 2017, s. 305 i n.
} 
i w ten sposób może o sobie stanowić ${ }^{2}$. Do opisania tej naturalnej dla człowieka wolności Wojtyła używa określenia alteri incommunicabilis - osoba jest nieprzekazywalna, niedostępna; pojęcie to wskazuje również na fundamentalną wolność człowieka: „nikt nie może za mnie chcieć. Nikt nie może podstawić swojego aktu woli za mój”. Termin „samostanowienie” wyraża więc przynależną człowiekowi, niczym nieskrępowaną wolność.

Można powiedzieć, że tak określona wolność człowieka domaga się również wolności narodu. Aby wyjaśnić tę tezę, należy zastanowić się nad rozumieniem przez papieża pojęcia narodu. W książce pt. Pamięć i tożsamość Jan Paweł II wskazuje na związek narodu z naturą człowieka, która ma charakter społeczny ${ }^{4}$. Można dopatrzeć się tutaj nawiązania do filozofii społecznej Arystotelesa, który uważał człowieka za istotę z natury społeczną, czyli stworzoną do funkcjonowania wśród innych ludzi. Naród jawi się tutaj jako struktura wynikająca z natury człowieka, struktura ufundowana na tej właśnie potrzebie życia we wspólnocie. Jan Galarowicz, nawiązując do myśli Wojtyły, stwierdza, że naród jest „jednym z podstawowych sposobów przejawiania się i urzeczywistniania człowieczeństwa, jednym z głównych sposobów ludzkiego bycia"5. Naród to pewna wspólnota osób.

Każdy osoba jest wolna, każda ma prawo sama o sobie stanowić. Biorąc pod uwagę fakt, że naród stanowi podstawową społeczność osób, trzeba przyjąć, że również naród jako podmiot zbiorowy powinien mieć prawo sam o sobie stanowić. Nie jest to tożsame z prawem narodu do posiadania państwa, natomiast nie da się zaprzeczyć, że naturalnym następstwem przyjętej wizji narodu jest stworzenie przez niego państwa, które byłoby gwarantem i wykonawcą jego samostanowienia.

\section{Wolność - zobowiązanie i wezwanie do ofiary}

W przemówieniu wygłoszonym z okazji dwusetnej rocznicy uchwalenia Konstytucji 3 Maja Jan Paweł II podkreśla: „Wolności nie można tylko posiadać, nie można jej wyłącznie używać. Trzeba ją stale zdobywać i tworzyć”" Wolność łączy się z wysiłkiem. Dobrze widać to na przykładzie wysiłku wkładanego w budowanie wolności ojczyzny przez narody świata. W szczególności zaś Jan Paweł II na-

\footnotetext{
${ }^{2}$ Por. K. Wojtyła, Osoba i czyn, [w:] K. Wojtyła, Osoba i czyn oraz inne studia antropologiczne, Lublin 2011, s. 152n.

${ }^{3}$ K. Wojtyła, Miłość i odpowiedzialność, Lublin 2010, s. 26.

${ }^{4}$ Jan Paweł II, Pamięć i tożsamość, Kraków 2005, s. 73.

${ }^{5} \mathrm{~J}$. Galarowicz, Wprowadzenie do antropologii filozoficznej, dz. cyt., s. 307.

${ }^{6}$ Jan Paweł II, Przemówienie wygłoszone w czasie nabożeństwa dziękczynnego z okazji 200. rocznicy Konstytucji 3 maja, Warszawa, 8.06.1991, [w:] https://opoka.org.pl/biblioteka/W/WP/ jan_pawel_ii/przemowienia/35warszawa_08061991.html (04.09.2018).
} 
wiązuje do historii Polski i starań Polaków o odzyskanie niepodległości. Podkreśla wysiłek, na jaki zdobył się naród polski, aby doprowadzić po I i II wojnie światowej do odzyskania niepodległości ${ }^{7}$. Pisze: „Ziemia odebrana narodowi przemocą staje się niejako głośnym wołaniem w kierunku «ducha» narodu. Duch narodu się budzi, żyje nowym życiem i z kolei walczy, aby były przywrócone ziemi jej prawa"s. Wolność wymaga ofiary - poświęcenie życia dla walki o niepodległość to nie tyle zasługa, ile obowiązek każdego członka narodu.

Ważną rolę w tekstach Jana Pawła II o ojczyźnie odgrywa pojęcie patriotyzmu. Oznacza ono umiłowanie tego, co ojczyste ${ }^{9}$. Konieczne wydaje się w tym miejscu odróżnienie patriotyzmu od nacjonalizmu. Ten drugi bowiem uznaje tylko dobro własnego narodu i nie liczy się z prawami innych, patriotyzm zaś jest miłością własnej ojczyzny, która jednak przyznaje innym narodom takie same prawa jak własnemu ${ }^{10}$. Papież stwierdza, że próbą dla patriotyzmu staje się zagrożenie „tego dobra, jakim jest ojczyzna" ${ }^{11}$. Miłość wzywa do ofiary, miłość ojczyzny wzywa do ofiarowania swego życia na rzecz wolności narodu.

Myśl o wyzwaniach wobec członków narodu płynących ze strony wolności, dobrze wyraził Karol Wojtyła w wierszu zatytułowanym Myślac ojczyzna:
Wolność stale trzeba zdobywać
nie można jej tylko posiadać.
Przychodzi jako dar,
utrzymuje się poprzez zmaganie.
Dar i zmaganie
wpisują się w karty ukryte,
a przecież jawne.
Całym sobą płacisz za wolność - więc to wolnością nazywaj,
że możesz płacąc
ciągle na nowo siebie posiadać. ${ }^{12}$

Ten fragment uwypukla dwie myśli obecne także w innych rozważaniach papieża Polaka na temat niepodległości ojczyzny. Pierwsza wskazuje wolność jako dar oraz zmaganie. Wolność trzeba czasem wypracowywać w pocie czoła, pokonując zewnętrzne przeciwności oraz opór własnego wnętrza - można bowiem wycofać

\footnotetext{
${ }^{7}$ Por. Jan Paweł II, Pamięć i tożsamość, dz. cyt., s. 56.

${ }^{8}$ Jan Paweł II, Pamięć i tożsamość, dz. cyt., s. 67.

${ }^{9}$ Por. Jan Paweł II, Pamięć i tożsamość, dz. cyt., s. 71.

${ }^{10}$ Por. Jan Paweł II, Pamięć i tożsamość, dz. cyt., s. 73.

${ }^{11}$ Por. Jan Paweł II, Pamięć i tożsamość, dz. cyt., s. 72.

${ }^{12}$ K. Wojtyła, Myśląc Ojczyzna, Lublin 1997, s. 7.
} 
się, nie podjąć wezwania płynącego ze strony wolności. Jedni „nie dopłacają”, inni muszą „nadpłacić” - zapisuje Wojtyła ${ }^{13}$. Wolność nieraz domaga się ofiary życia:

na ołtarzu samostanowienia

płonęły ofiary pokoleń -

przejmujące wołanie wolności

silniejszej niż śmierć. ${ }^{14}$

Wolną ojczyznę można nazwać wyzwaniem dla ludzi. Nie tylko ci, którzy walczyli o wyzwolenie ojczyzny spod jarzma zaborcy czy okupanta zostali powołani do służenia ojczyźnie. Wezwanie takie się skierowane jest również do tych, którzy żyją w czasach pokoju. Wolność to nieociosany kamień domagający się ludzkiego wysiłku. Być może dlatego właśnie papież modlił się tak żarliwie podczas nabożeństwa dziękczynnego z okazji dwusetnej rocznicy uchwalenia Konstytucji 3 Maja: „I tak jak cudownie przeprowadziłeś nas suchą nogą przez Morze Czerwone, naucz nas być wolnymi" ${ }^{15}$. Wolność nie jest darem prostym, lecz wymaga trudu - wolności trzeba się nauczyć.

Druga myśl obecna w przywołanym wyżej fragmencie poematu pt. Myśląc ojczyzna uwypukla związek wolności z samostanowieniem osoby. Walka o wolność ojczyzny przedstawia się tutaj jako walka o prawo do stanowienia o sobie - w gruncie rzeczy jest to walka o prawo do bycia człowiekiem. Odebranie wolności narodowi zamyka drogi stanowienia o sobie poszczególnym jego członkom. Człowiek, któremu nie pozwala się w pełni korzystać z przyrodzonej wolności, jest jak roślina, która więdnie z braku wody. Stąd w wierszu wezwanie do płacenia za wolność całym sobą - jest to nie tylko próba wyzwolenia narodu, ale również próba przywrócenia osobie należnej wolności.

\section{Chrystus drogą narodu}

W tekstach Jana Pawła II dotyczących zagadnień narodu, ojczyzny czy niepodległości można dostrzec wyraźne przekonanie, że naród to przede wszystkim pewnego rodzaju rodzina ludzka; nie można też patrzeć na naród bez dostrzegania, że tworzą go konkretne osoby obdarzone godnością. Godność każdego człowieka

${ }^{13}$ Por. K. Wojtyła, Myślac Ojczyzna, dz. cyt., s. 7.

${ }^{14} \mathrm{~K}$. Wojtyła, Myśląc Ojczyzna, dz. cyt, s. 8.

${ }^{15}$ Jan Paweł II, Przemówienie wygłoszone w czasie nabożeństwa dziękczynnego z okazji 200. rocznicy Konstytucji 3 maja, Warszawa, 8.06.1991, [w:] https://opoka.org.pl/biblioteka/W/WP/ jan_pawel_ii/przemowienia/35warszawa_08061991.html (4.09.2018). 
stanowi pewien drogowskaz, określający, w jaki sposób należy i w jaki sposób nie należy pojmować kategorii narodu.

Warto przypomnieć analizy Karola Wojtyły dotyczące idei uczestnictwa, zawarte w dziele Osoba i czyn. Autor stwierdza, że sposób funkcjonowania wspólnot powinien być oparty właśnie na idei uczestnictwa, która zdecydowanie różni się od zwykłego członkostwa osoby w jakiejś grupie. Dzięki uczestnictwu „człowiek, działając wspólnie z innymi, zachowuje to wszystko, co wynika ze wspólnoty działania, a równocześnie - przez to właśnie - urzeczywistnia wartość personalistyczną własnego czynu"16. Człowiek uczestniczy we wspólnym działaniu i w realizacji wspólnego dobra, a jednocześnie spełnia przez to samego siebie. Uczestnictwo sprawia, że osoba i jej działanie nie rozpływają się w tłumie i działaniach społeczności. Dzięki uczestnictwu osoba spełnia się we wspólnocie.

Przedstawienie idei uczestnictwa pozwala lepiej zrozumieć pojęcie narodu i sposób jego funkcjonowania. Członkowie narodu powinni być ze sobą powiązani poprzez uczestnictwo - tylko ono może zapewnić współistnienie w narodzie poszczególnych osób, tworzących wspólnotę. Dzięki uczestnictwu osoba i wspólnota „przylegają do siebie” ${ }^{17}$. O tym, że Jan Paweł II rozumiał naród poprzez ideę uczestnictwa, świadczyć może fragment homilii wygłoszonej przez niego w Warszawie na Placu Zwycięstwa w czasie pierwszej pielgrzymki apostolskiej do Polski. Pisał wówczas: „Jeśli jest rzeczą słuszną, aby dzieje narodu rozumieć poprzez każdego człowieka w tym narodzie - to równocześnie nie sposób zrozumieć człowieka inaczej jak we wspólnocie, którą jest jego naród” ${ }^{18}$. Osoba i naród „przylegają do siebie”. Aby zrozumieć naród, trzeba rozumieć człowieka.

Problem rozumienia człowieka przyjmuje w nauczaniu Jana Pawła II miejsce szczególne. W swojej pierwszej encyklice Redemptor hominis papież podkreśla, że człowiek jest drogą Kościoła ${ }^{19}$. Jest nią dlatego, że człowieka - każdego bez wyjątku - Chrystus odkupił i z każdym jest „w jakiś sposób” zjednoczony. Takie spojrzenie na człowieczeństwo stanowi znamienny rys antropologii zawartej w papieskim nauczaniu. To zjednoczenie Chrystusa z każdym człowiekiem jest tak silne, że człowieka nie można zrozumieć bez Chrystusa - Jan Paweł II podkreślał to wielokrotnie ${ }^{20}$. W książce pt. Pamięć i tożsamość stwierdził, że oderwanie człowieka od Chrystusa skutkuje niemożnością osiągnięcia pełni człowieczeństwa -

${ }^{16}$ K. Wojtyła, Osoba i czyn, dz. cyt., s. 309.

${ }^{17}$ K. Wojtyła, Osoba i czyn, dz. cyt., s. 316.

${ }^{18}$ Jan Paweł II, Homilia wygłoszona $w$ Warszawie na Placu Zwycięstwa w dniu 2 czerwca 1979 roku, nr 3, [w:] Jan Paweł II, Nauczanie papieskie, II, 1, 1979, s. 600.

${ }^{19}$ Por. Jan Paweł II, enc. Redemptor hominis, nr 14.

${ }^{20}$ Zob. np. Jan Paweł II, Pamięć i tożsamość, dz. cyt., s. 104; Jan Paweł II, Nie można usunać Chrystusa z historii człowieka, [w:] Jan Paweł II, Nauczanie Papieskie, II, 1, 1979, s. 599. 
człowiek staje się latoroślą odciętą od winnego krzewu ${ }^{21}$. Osoba Jezusa Chrystusa stanowi klucz do zrozumienia człowieczeństwa - bez tego klucza będziemy zagubieni w swoich próbach stworzenia adekwatnej antropologii.

$Z$ racji tego, że naród tworzą ludzie, to także losy narodu nie dają się pojąć bez umieszczenia ich w tym szczególnym kluczu chrystologicznym. Papież podkreśla, że

Chrystusa nie można wyłączyć z dziejów człowieka w jakimkolwiek miejscu na ziemi. Nie można też bez Chrystusa zrozumieć dziejów Polski - przede wszystkim jako dziejów ludzi, którzy przeszli i przechodzą przez tę ziemię. Dzieje ludzi! Dzieje narodu są przede wszystkim dziejami ludzi. A dzieje każdego człowieka toczą się w Jezusie Chrystusie. W nim stają się dziejami zbawienia. ${ }^{22}$

Papieskie rozważania dotyczące narodu nie pomijają zasadniczego w chrześcijaństwie nakierowania na zbawienie. Jan Paweł II wskazuje na eschatologiczny wymiar każdego narodu. Ten wymiar musi istnieć ze względu na to, że powołanie każdego człowieka, członka narodu, jest eschatologiczne i „rzutuje w jakiś sposób na dzieje narodów"23. Takie spojrzenie na losy człowieka i dzieje narodu umieszcza historię ludzkości w przestrzeni wiary oraz szczególnego sensu. To eschatologiczne odniesienie pokazuje, że życie ludzkie ma sens oraz że mają sens dzieje narodów ${ }^{24}$. W takim też kluczu żadne wydarzenie $\mathrm{z}$ historii danego narodu nie jawi się jako przypadkowe i bezsensowne, lecz ukazuje się jako przepełnione głębszym sensem, jako otwarte na nadzieję płynącą z wiary.

Szczególny nacisk kładł Jan Paweł II na przedstawienie historii własnego narodu w perspektywie eschatologicznej. Był przekonany, że

nie sposób zrozumieć dziejów narodu polskiego (...) bez Chrystusa. Jeślibyśmy odrzucili ten klucz do zrozumienia naszego narodu, narazilibyśmy się na zasadnicze nieporozumienie. Nie rozumielibyśmy samych siebie. Nie sposób bowiem zrozumieć tego narodu, który miał przeszłość tak wspaniałą, ale zarazem tak straszliwie trudną bez Chrystusa. ${ }^{25}$

${ }^{21}$ Por. Jan Paweł II, Pamięć i tożsamość, dz. cyt., s. 103n.

${ }^{22}$ Jan Paweł II, Nie można usunać Chrystusa z historii człowieka, [w:] Jan Paweł II, Nauczanie Papieskie, II, 1, 1979, s. 600.

${ }^{23}$ Jan Paweł II, Pamięć i tożsamość, dz. cyt., s. 80.

${ }^{24}$ Por. Jan Paweł II, Pamięć i tożsamość, dz. cyt., s. 80.

${ }^{25}$ Por. Jan Paweł II, Nie można usunąć Chrystusa z historii człowieka, [w:] Jan Paweł II, Nauczanie papieskie, II, 1, 1979, s. 600. 
Mimo okropności wojen, Jan Paweł II potrafił spoglądać na losy narodów przez pryzmat wiary, wierząc w nierozerwalne zjednoczenie dziejów ludzkości z dziejami wiary, a także losów pojedynczych ludzi z osobą Chrystusa.

W takim świetle niepodległość narodu staje się szansą, a nawet rodzajem daru przekazanego narodowi, aby w swojej wolności kroczył ku Bogu, by swoimi wysiłkami dążył do utrzymania tego wszczepienia w winną latorośl. Według Jana Pawła II „wolności (...) nie można zrozumieć bez odniesienia jej do prawdy objawionej przez Jezusa Chrystusa”26. Wolność winna służyć upodabnianiu się do Chrystusa, a nie być pretekstem do moralnej anarchii. Papież podkreślał, że żadna wolność a można powiedzieć, że również niepodległość żadnego narodu - nie może kierować się przeciw człowiekowi w tym, czym on jest, lub przeciw człowiekowi w jego relacji do innych i do Boga ${ }^{27}$. Niepodległość narodu ma służyć człowiekowi nie tylko w sprawach doczesnych, ale również w jego rozwoju duchowym i wędrówce ku niebu. Należy pamiętać, że drogą niepodległego narodu winien być Chrystus.

\section{Zakończenie}

Zarysowana w tej pracy wizja narodu w nauczaniu Jana Pawła II ukazuje nierozerwalny związek między losami narodu oraz osobą Jezusa Chrystusa. Niepodległość, czyli usankcjonowana wolność narodu nie może być rozpatrywana bez odniesienia eschatologicznego. Wolność to rodzaj daru dla osoby, daru, z którego trzeba mądrze korzystać, ale także rodzaj zobowiązania - o wolność czasem trzeba walczyć i w imię wolności podjąć ofiarę. Doskonale widać to na przykładzie dziejów narodów - o niepodległość trzeba walczyć, a kiedy się ją zdobędzie, należy jej strzec, ale nie chodzi tylko o walkę rozumianą dosłownie, lecz o szczególną pracę każdego członka narodu, pracę nad własnym człowieczeństwem i nad relacjami z bliźnimi. Wolna ojczyzna, to zadanie nałożone na barki wszystkich członków narodu, którzy muszą pamiętać, że ich dzieje mają nie tylko wymiar doczesny, ale że są drogą ku ojczyźnie niebieskiej. Niech tę prawdę wyrażą słowa poematu Karola Wojtyły:

\footnotetext{
Ucząc się nowej nadziei, idziemy poprzez ten czas

ku ziemi nowej.

I wznosimy ciebie,
}

\footnotetext{
${ }^{26}$ Por. Jan Paweł II, Wspominając Deklarację Niepodległości, [w:] Jan Paweł II, Nauczanie papieskie, II, 2, 1979, s. 289.

${ }^{27}$ Por. Jan Paweł II, Wspominając Deklarację Niepodległości..., dz. cyt., s. 289.
} 
ziemio dawna,

jak owoc miłości pokoleń,

która przerosła nienawiśćc 28

\section{Abstract \\ A free homeland - a gift and commitment}

The text concerns an issue of homeland's freedom according to John Paul II's analysis about notions of nation, homeland and freedom. The close connection between freedom of a human and freedom of a nation is emphasised in the text - from human right to be free flows a right for nation to be free. The important strain in the text is also the importance of Christological way of interpretation of history of nations - freedom of a nation is given for its members to become similar to Christ. It is impossible to understand a human and a nation without Christ.

Keywords: nation, homeland, freedom

${ }^{28}$ K. Wojtyła, Myśląc Ojczyzna, dz. cyt., s. 15. 